\title{
DEVELOPMENT OF A MULTI-PURPOSES MACHINE FOR SECONDARY TILLAGE, FERTILIZING AND PLANTING SOME MEDICINAL AND AROMATIC PLANTS
}

\author{
El-Shazly M.A. *, M.M. Morad**, M.M. Ali***, K.I. Wasfy****
}

\section{ABSTRACT}

Field experiments were carried out to develop a multi-purposes machine for secondary tillage, fertilizing and planting some medicinal and aromatic plants; fennel (Foeniculum vulgare Mill.) and caraway (Carum carvi L.). The combination machine performance was evaluated comparing with the traditional method as a function of change in forward speed $(2.1,3.6,4.5$ and $6.3 \mathrm{~km} / \mathrm{h})$, in terms of soil physical properties, seed scattering, emergence ratio, yield, power, energy and cost requirements. The experimental results revealed that soil physical properties, seed scattering, emergence, energy requirements and operational cost were in the optimum region under the following recommended conditions:

- The use of the developed combination machine for secondary tillage, fertilizing and planting as a multi-purposes machine because of its minimum both energy and cost, added to the improvement of soil properties.

- Adjust fluted roll length of the feeding device at $10 \mathrm{~mm}$ for seeds and 22 mm for fertilizer to obtain the desired quantity of seeds and fertilizers per feddan.

- Operate the developed combination machine at forward speed of about $4.5 \mathrm{~km} / \mathrm{h}$, which corresponded to kinematic parameter of 3.28 for seeds and 7.5 for fertilizers.

\section{INTRODUCTION}

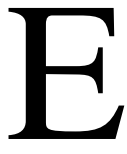
gyptian agriculture has been and still the backbone of national economy. Therefore, it is vital that any program for economic development should bear on getting the highest production from the land using the best agricultural techniques with least effort and cost.

\footnotetext{
* Prof. and Head of Agric. Eng. Dep., Fac. Agric. Zagazig Univ., Egypt.

** Prof. of Agric. Eng. Dep., Fac. Agric. Zagazig Univ. ,Egypt.

*** Assistant Prof. of Agric. Eng. Dept., Fac. of Agric., Zagazig Univ., Egypt.

**** Assistant Lecturer of Agric. Eng. Dep., Fac. Agric. Zagazig Univ., Egypt.
} 
The medicinal and aromatic plants are considered one of the most important untraditional agricultural commodities which can be used as a base for Egyptian national income development. However, the value of its exports is estimated at about $6.6 \%$ of the total value of the Egyptian agricultural exports as an average for the period (2003-2008)

(EI-

Eshmawy and Ali 2010). The demand for medicinal and aromatic plants is increasing continuously in both industrialized and developed countries which leads to increase their prices. This in turn, raised the carefully of the agricultural policy planners towards these plants. Fennel and caraway are considered to be two of the most important medicinal and aromatic plants in Egypt as they participate in the local consumption added to export value and different aspects. Agricultural operations required for medicinal and aromatic plants production were carried out manually. So, development of a combination machine for secondary tillage, fertilizing and planting some medicinal and aromatic plants is very important in saving hand labor, improving production, and allowing further mechanization. El-Nakib and Fouad (1990) designed a combined tiller and planter to prepare seedbed and plant no tilled field. Such machine can be used instead of chisel plow, rotary plow and planter. They also determined soil bulk density and penetration resistance at different working speeds. They found that the values of soil bulk density and penetration resistance decreased after tillage. Abdou (1995) designed and manufactured a combination unit with consisted that the designed unit gave a $100 \%$ degree of soil pulverization for of 7 shares chisel plow, rotary plow and seed drill. The obtained data showed size less than $10 \mathrm{~cm}$, saved $64 \%$ of fuel consumption and $36 \%$ of operational time compared with single machines. Imbabi (2001) studied the effects of a combined unit (seedbed preparation and planting of wheat seeds) and seed-drill machine to evaluate seedbed preparation process through clod size, slip, time requirement, fuel consumed, seeds requirement, emergence and costs. The data indicated that applying the combination unit saved $58 \%$ in the required operation time in preparing and planting the soil and saved about 40 L.E./yr/fed. Morad et al. (2001) developed a combination unit for secondary tillage and seeding wheat and compared with the conventional methods. The combination performance in terms of soil bulk 
density, soil penetration resistance, wheat yield, power and energy requirements was investigated as a function of change in forward speed, working depth and soil moisture content under dry and wet conditions. The experimental results revealed the following: the developed combination unit is recommended to be used for secondary tillage and seeding wheat as it reduces both energy and cost, the developed combination unit is recommended to be operated at a forward speed of 4 $\mathrm{km} / \mathrm{h}$ and working depth of $12 \mathrm{~cm}$ and the recommended moisture contents are $25 \%$ and $28 \%$ under dry and wet conditions, respectively. Bertocco (2007) discussed various models of combination seed drills. In Italy the most popular models combine the seed drill with a rotary cultivator. The roller, which levels the surface and is placed between the cultivator and the drill, must be sufficiently robust to produce a fine seedbed. Combination machines are beneficial to the farmer in that the components can be used separately if required, that they reduce the number of operations and so the danger of soil compaction and that they also reduce labor hours and costs.

As mentioned, it is very important to look after medicinal and aromatic plants to optimize their mechanization system.

\section{So, the objectives of this work are to:}

- Develop a multi-purposes machine for secondary tillage, fertilizing and planting some medicinal and aromatic plants.

- Compare the developed machine performance with the conventional method.

- Optimize some operating parameters affecting the performance of the developed machine.

- Evaluate the developed machine from the economic point of view.

\section{MATERIALS AND METHODS}

Field experiments were carried out in clay soil through agricultural season of 2010/2011 at Hehia farm, Sharkia Governorate, Egypt to develop a combination machine for secondary tillage, fertilizing and planting some medicinal and aromatic plants and evaluate its performance. The mechanical analysis of the experimental soil was $51.49 \%$ clay, $6.21 \%$ silt and $42.30 \%$ sand. 


\section{MATERIALS:}

\section{Plants}

Two types of medicinal and aromatic plants; fennel (Foeniculum Vulgare Mill.) and caraway (Carum carvi L.) were used.

\section{Fertilizer}

The used fertilizer (complex granular NPK) was Nitrophoska blue special. Each compound granular contained all macro and micro nutrients.

\section{Machinery and equipment}

The following machines were used in carrying out this investigation:

3.1. Tractor Universal $650 \mathrm{M}$ : Tractor Universal $650 \mathrm{M}(2 \mathrm{WD})$, made in Romania, four stroke, Diesel with direct injection, 4 cylinders, engine power $55.15 \mathrm{~kW}$ (75 hp), engine rated speed 1440 r.p.m, mass $3820 \mathrm{~kg}$.

3.2. Tractor Kubota V 1702 - DI - A: Tractor L 2850 (4WD), made in Japan, engine power $25.4 \mathrm{~kW}$ (34 hp), direct injection, water cooled, 4 cycles diesel, 4 cylinders, engine rated speed 2600 r.p.m, mass $1230 \mathrm{~kg}$.

3.3. The chisel plow: Mounted chisel plow three point hitch, made in Behera company, Egypt, 7 blades, working width $175 \mathrm{~cm}$, mass $225 \mathrm{~kg}$. 3.4. Disk harrow: Mounted disk harrow (single action), model 28 dischi, made in Italy, 28 disks, disk diameter $40 \mathrm{~cm}$, plain, working width 150 $\mathrm{cm}$, mass $500 \mathrm{~kg}$.

3.5. Land leveler: Trailed land leveler, made in Tanta motors company, Egypt, working width $240 \mathrm{~cm}$, mass $370 \mathrm{~kg}$.

3.6. Seed drill: Mounted seed drill, model Colorado, made in Italy, 21 tubes, spacing between tubes $10 \mathrm{~cm}$. Distance between rows for the mentioned seed drill is adjusted to be $45 \mathrm{~cm}$ to be suitable for planting fennel and caraway, mass $350 \mathrm{~kg}$.

\subsection{The developed machine}

A multi-purposes machine for secondary tillage, fertilizing and planting some medicinal and aromatic plants was developed and manufactured from low costs, local materials to overcome the problems of high power and high cost requirements under the use of conventional methods. The proposed designed unit was mounted on three point hitches at the rear of a Kubota $25.4 \mathrm{~kW}$ (34 hp) tractor. The developed multi-purposes machine consisted mainly of secondary tillage unit, fertilizing unit, planting unit, transmission system, frame and land wheels as shown in 
Figs. (1 and 2).

3.7.1. The secondary tillage unit: The secondary tillage unit was a land roller type. It was constructed of a number of 15 wheel sections and fixed on the shaft. The shaft was fitted by two ball bearing, carried by two iron steel (U section $320 \times 340 \mathrm{~mm}$ ) and fixed beside the frame. There were two flange-coupling connected to ends of the shaft to prevent the wheels from the lateral movement during operating. The roller was hollow and cast out of semi-steel with a mass of $225 \mathrm{~kg}$.

\subsubsection{The fertilizing unit}

The fertilizing unit was consisted of the following main parts:

- The fertilizer hopper: Fertilizer hopper was mounted on the front of the frame and built from sheet steel of $3 \mathrm{~mm}$ thickness. It had a rectangular shape at the top of $680 \times 360 \mathrm{~mm}$. The full hopper capacity was $100 \mathrm{~kg}$. It had a trapezoid cross section, this section was inclined to the side walls angle of $50^{\circ}$, while the repose angle of Nitrophoska fertilizer was $18^{\circ}$.

- The fertilizing device: The fertilizing device of fluted wheel type consisted of two plastic gears with a horizontal axis (feed shaft). The feed shaft was made of steel and fixed on the bottom of fertilizing hopper. It was operated by means of sprockets and chains powered from the ground wheel. The feeders rotate with the shaft in the cases (housing), bring fertilizers and eject them into the funnels of the tubes through the gates.

- The tubes: Two smooth tubes from the inside of $20 \mathrm{~mm}$ diameter with $45 \mathrm{~cm}$ distance between them for fertilizer were attached to the holes at the bottom fertilizer hoppers. These tubes conveyed the fertilizers flow from the feed unit to the furrow opener.

- The agitators: The agitator was fixed inside the hopper and made of steel shaft to keep fertilizer moving and prevent vaulting in the hopper. The agitators were operated by means of sprockets and chains powered from the ground wheel.

- The control gates: Slide control gates fixed on the hopper bottom to control the amount of fertilizer flow and thereby capture the fertilizers from hopper to the feeding device. 


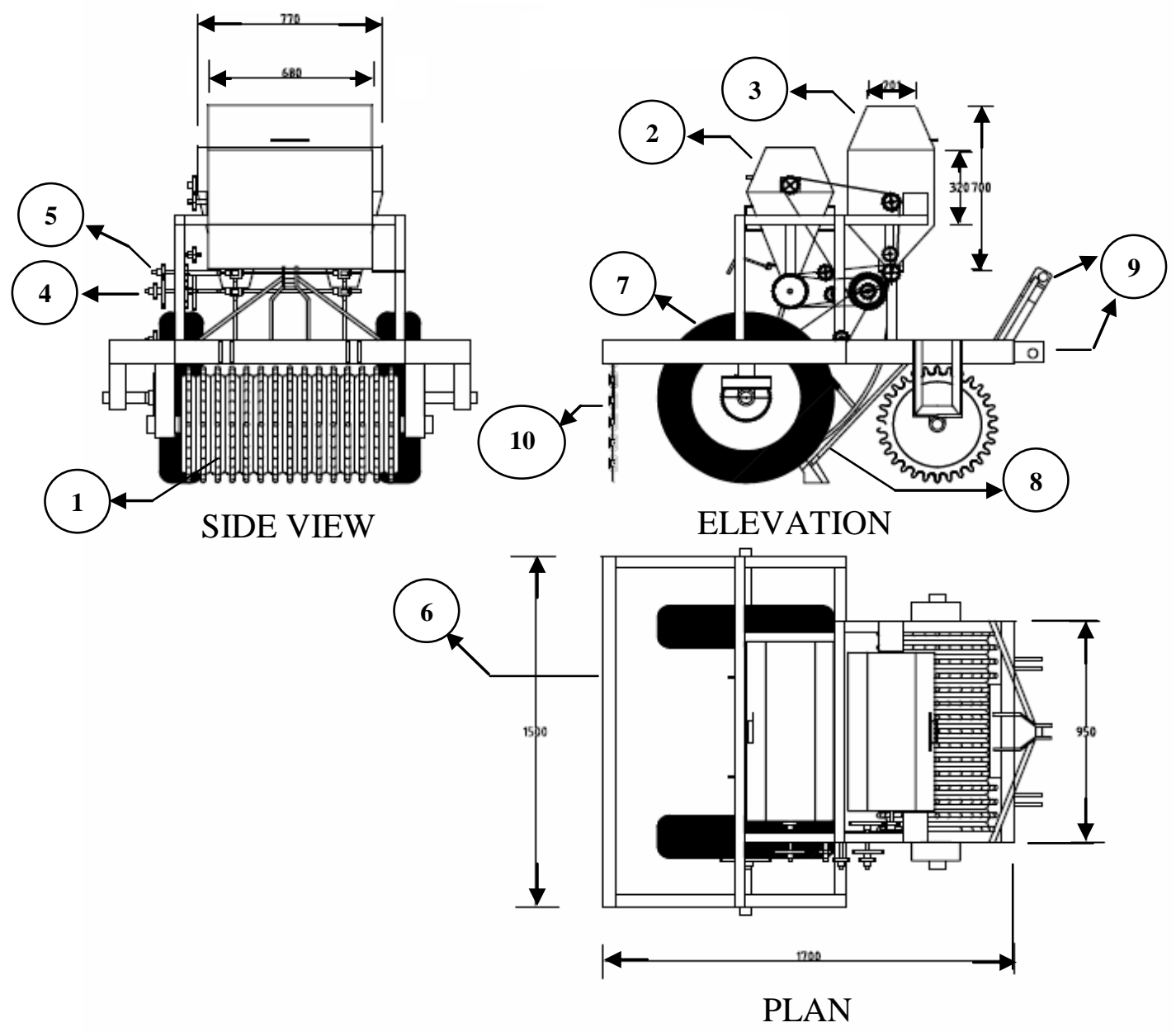

All dimensions in mm.

\begin{tabular}{|c|l|c|l|}
\hline No. & Part name & No. & Part name \\
\hline $\mathbf{1}$ & Land roller & $\mathbf{6}$ & Frame \\
\hline $\mathbf{2}$ & Seed hopper & $\mathbf{7}$ & Ground wheel \\
\hline $\mathbf{3}$ & Fertilizer hopper & $\mathbf{8}$ & Furrow opener \\
\hline $\mathbf{4}$ & Seed shaft & $\mathbf{9}$ & Point hitches \\
\hline $\mathbf{5}$ & Fertilizer shaft & $\mathbf{1 0}$ & Covering unit \\
\hline
\end{tabular}

Fig. (1): The views of the developed combination machine. 

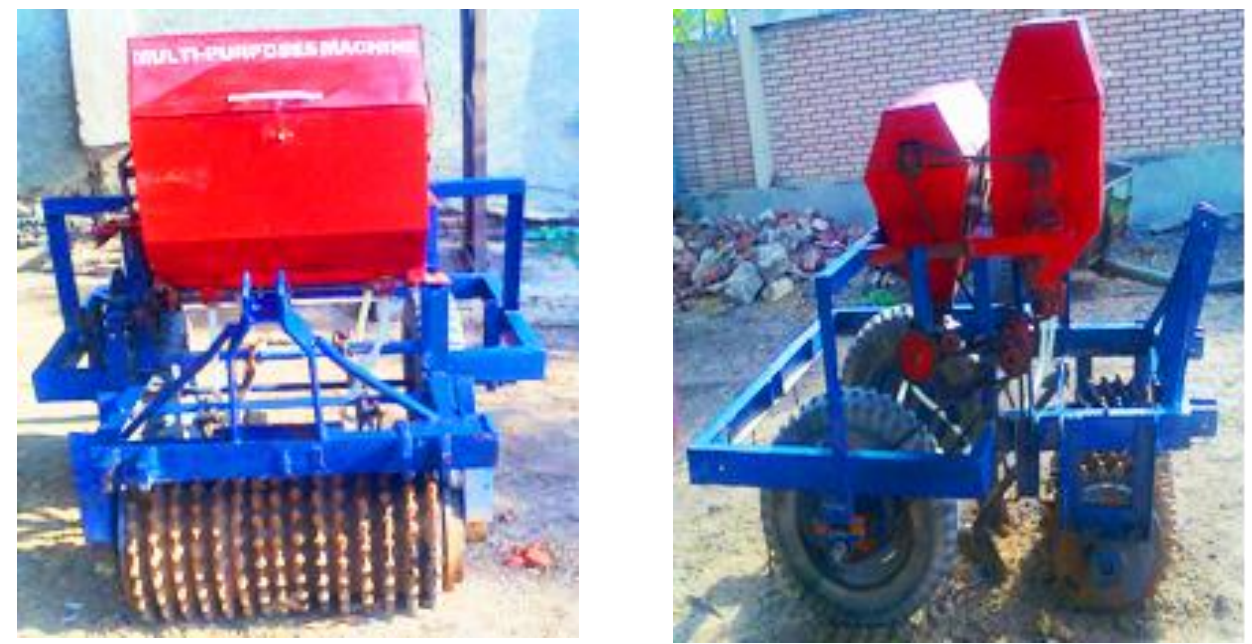

Fig. (2): The developed combination machine

\subsubsection{The planting unit}

The planting unit was consisted of the following main parts:

- The seed hopper: Two seed hoppers were mounted on the rear of the frame and built from sheet steel of $3 \mathrm{~mm}$ thickness. The hopper was rectangular shaped cross section at the top of $360 \times 360 \mathrm{~mm}$. The full capacity was $15 \mathrm{~kg}$ per each hopper. In order to facilitate the flow of seeds to slide down, the hopper walls must be inclined under a relevantly large angle of $60^{\circ}$ while the repose angle of both fennel and caraway seeds was $32^{\circ}$.

- The planting device: The planting device of fluted wheel type consisted of two plastic gears with a horizontal axis (feed shaft). The feed shaft was made of steel and fixed on the bottom of planting hopper.

It was operated by means of sprockets and chains powered from the ground wheel. The feeders rotate with the shaft in the cases (housing), bring seeds and eject them into the funnels of the tubes through the gates.

- The tubes: Two smooth tubes from the inside of $20 \mathrm{~mm}$ diameter with $45 \mathrm{~cm}$ distance between them for seeds were attached to the holes at the bottom of seeds hoppers with $45 \mathrm{~cm}$ between each. These tubes conveyed the seeds flow from the feed unit to the furrow opener.

- The agitators: The agitators were fixed inside the seed hoppers and made of steel shaft to keep seed moving and prevent vaulting in the hopper. The agitators were operated by means of sprockets and chains powered from the ground wheel. 
- The control gates: Slide control gates fixed on each hopper side to control the amount of seed flow and capture the seeds from hopper to the feeding device.

3.7.4. The furrow openers: Two chisel furrow openers were made from steel to cut a furrow at the desired depth into which both seeds and fertilizer fall and partially cover the seeds and fertilizer with the soil.

3.7.5. Transmission system: Sprockets and chains were used as transmission system. They transferred the motion from ground wheel to the metric device and gave the availability of changing feed shaft rotating speed to allow different application of feed rates.

3.7.6. The covering device: Simple drag chains, which merely covered the seeds with loose soil, were satisfactory for planting machines under most conditions. The chains covering unit were hitched with the frame.

3.7.7. The frame: The all previous units and their parts were fixed on the frame. The frame was made of iron steel rectangular shaped $(850 \times 650 \mathrm{~mm})$ in the front and $(1450 \times 1000 \mathrm{~mm})$ in the end and then fixed above two special iron connections fitted on the axes of land wheels (73.5 $\mathrm{cm}$ diameter) by two ball bearings.

\section{METHODS:}

The experimental area was about three feddans cultivated with fennel and caraway. They divided into two equal plots (1.5 feddans each). Every plot had dimensions of $(105 \times 60 \mathrm{~m})$.

Two experimental groups namely A and B were carried out and replicated three times in a completely randomized block design:

A. The first group of tests was conducted under chiseling twice by chisel plow, harrowing by disk harrow, leveling by land leveler, fertilizing and planting by seed-drill.

B. The second group of tests was carried out under chiseling twice by chisel plow and the developed machine for secondary tillage, fertilizing and planting.

The fertilizing depth was about $2.5 \mathrm{~cm}$ and the average forward speed was about $4 \mathrm{~km} / \mathrm{h}$. Fertilizing required about $100 \mathrm{~kg} /$ fed of Nitrophoska blue special fertilizer for fennel and caraway. The planting depth was about 2.5 $\mathrm{cm}$ and both the seed drill and the developed machine forward speeds were $(2.1,3.6,4.5$ and $6.3 \mathrm{~km} / \mathrm{h})$. Planting required about $6 \mathrm{~kg} / \mathrm{fed}$ 
of seeds under rows spacing of about $45 \mathrm{~cm}$ for fennel and caraway.

\section{Adjustment of feeding device}

The used feeding device (fluted wheel) was adjusted by adjusting its kinematic parameter. The kinematic index $\lambda$ for fertilizing and planting was the ratio of device peripheral speed $(u)$ to the machine forward speed (v):

$$
\lambda=\mathrm{u} / \mathrm{v}
$$

\section{- Kinematic parameter of fertilizer feeding device}

The tests were run under a constant machine forward speed of $3.6 \mathrm{~km} / \mathrm{h}$ and different feed shaft peripheral speeds of 7.39, 6.43, 6.00 and $5.35 \mathrm{~m} / \mathrm{s}$ (192, 167, 156 and 139 r.p.m.), which corresponded to different kinematic parameters of 7.39, 6.43, 6.00 and 5.35. Another tests were run side by side with the kinematic parameter under different fluted roll working lengths of between 0 to $36 \mathrm{~mm}$. Preliminary experiments showed that the optimum kinematic parameter which gave the required rate of fertilizing was 6.00 and the optimum fluted roll length of the feeding device for fertilizer was $22 \mathrm{~mm}$.

\section{- Kinematic parameter of planter feeding device}

In this study, the tests were run under a constant machine forward speed of $3.6 \mathrm{~km} / \mathrm{h}$ and different feed shaft peripheral speeds of 3.43, 2.77, 2.62 and $2.39 \mathrm{~m} / \mathrm{s}(89,72,68$ and 62 r.p.m.), which corresponded to different kinematic parameters of 3.43, 2.77, 2.62 and 2.39. Another tests were run side by side with the kinematic parameter under different fluted roll working lengths of between 0 to $36 \mathrm{~mm}$. Preliminary experiments showed that the optimum kinematic parameter which gave the required rate of seeding was 2.62 and the optimum fluted roll length of the feeding device for seeds was $10 \mathrm{~mm}$.

\section{- Measurements}

Evaluation of the developed machine comparing with the traditional method was carried out taking into consideration the following indicators

\section{1- Soil measurements}

\section{- Soil bulk density}

Soil bulk density before and after plowing, was determined according to Black et al. (1965) by using the following formula:

Where: $\rho_{\mathrm{d}}$ : Soil bulk density, $\mathrm{g} / \mathrm{cm}^{3}=\mathrm{m} / \mathrm{V}$ 
V: Total soil volume, $\mathrm{cm}^{3}$

The percentage of reduction in bulk density $(\Delta \rho \%)$ was calculated using the following formula :

$$
\Delta \rho(\%)=\frac{\rho_{1}-\rho_{2}}{\rho_{1}} \times 100
$$

Where: $\quad \rho_{1}$ : soil bulk density before plowing, $\mathrm{g} / \mathrm{cm}^{3}$

$\rho_{2}$ : soil bulk density after each operation, $\mathrm{g} / \mathrm{cm}^{3}$

\section{- Soil penetration resistance}

Penetration resistance values were measured directly before and after each operation using the cone penetrometer. The cone index had been defined as the force unit at depth of penetration according to the following: $\quad R=\frac{F}{A}$

Where: R: Soil penetration resistance, N/cm ${ }^{2} \quad$ F: Required force, $\mathrm{N}$

A: Projected area of penetrometer, $\mathrm{cm}^{2}$

The percentage of reduction in soil penetration resistance $(\triangle R \%)$ was calculated using the following formula :

$$
\Delta R(\%)=\frac{R_{1}-R_{2}}{R_{1}} \times 100
$$

Where: $R_{1}$ : Soil penetration resistance before plowing, $N / \mathrm{cm}^{2}$

$R_{2}$ : Soil penetration resistance after each operation, $N / \mathrm{cm}^{2}$

\section{2- Plant measurements}

\section{- Emergence ratio}

The emergence ratio was determined in the field after planting and irrigation. Emergence ratio was determined according to the following formula:

Emergence ratio $=\frac{\text { Average number of plants per square meter }}{\text { Average number of seeds per square meter }} \times 100$

\section{- Seed scattering}

The seed scattering was determined according to the following formula (Snedecor and cochran, 1967).

Where:

$$
C . V .=\frac{\sigma n-1}{\bar{x}} \times 100 \quad \sigma n-1=\frac{\sqrt{\sum(x-\bar{x})^{2}}}{n-1}
$$

C.V.: Coefficient of variation between row from average distance, $\%$ $\sigma n-1:$ Standard deviation $\bar{x}$ : The average distance

$\mathrm{x}$ : Distance between rows $\mathrm{n}$ : Number of readings

\section{- Fruit yield}

Randomized samples were taken from the field to calculate fruit yield. 
The yields of fennel and caraway were determined after harvesting and calculated in $\mathrm{Mg} / \mathrm{fed}$.

\section{3- Machine performance:}

\section{- Theoretical field capacity}

The theoretical field capacity is the rate of the field coverage that will be obtained if the machine is performance its function $100 \%$ of the time at the rated forward speed and always cover $100 \%$ of its rated width (Kepner et al. 1978). Thus, it calculated as:

$$
\mathrm{T}_{\mathrm{f} . \mathrm{c} .}=\left(\mathrm{W}_{\mathrm{m}} \times \mathrm{F}_{\mathrm{s}}\right) / 4.2
$$

Where: $T_{\text {f.c: }}$ Theoretical field capacity, fed/h

$\mathrm{W}_{\mathrm{m}}$ : Width of the machine, $\mathrm{m} \quad \mathrm{F}_{\mathrm{s}}$ : Forward speed, $\mathrm{km} / \mathrm{h}$

\section{- Actual field capacity}

Actual field capacity is based upon the total effective operating time (Kepner et al. 1978). Thus, it calculated as:

$$
A_{\text {f.c. }}=1 / T_{t}
$$

Where: $\quad A_{\text {f.c. }}$ : Actual field capacity, fed/h

$\mathrm{T}_{\mathrm{t}}$ : Actual total time in hours required per feddan, $\mathrm{h} / \mathrm{fed}$

\section{- Field efficiency}

The field efficiency was calculated by using the following formula:

$$
\eta_{\mathrm{f}}=\left(\mathrm{A}_{\text {f.c. }} / \mathrm{T}_{\text {f.c. }}\right) \times 100
$$

Where: $\eta_{\mathrm{f}}$ : Field efficiency, $\% \quad \mathrm{~T}_{\text {f.c.: }}$ Theoretical field capacity, fed $/ \mathrm{h}$

\section{- Fuel consumption}

Fuel consumption per unit time was determined by using a calibrated tank (Refilling method) to measure the volume of fuel consumed during the operation time.

\section{- Required power}

The required power was calculated using the following formula of Hunt (1983).

$$
E P=\left[\text { f.c. }(1 / 3600) P E \times \text { L.C.V. } \times 427 \times \eta_{t h b} \times \eta_{m} \times 1 / 75 \times 1 / 1.36\right], k W
$$

Where: $E P$ : Required power, $\mathrm{kW}$

f.c.: Fuel consumption, lit/h

$P E$ : Density of fuel, for diesel engines $=0.85 \mathrm{~kg} / \mathrm{lit}$

L.C.V.: Lower calorific value of fuel, $11.000 \mathrm{kcal} / \mathrm{kg}$

$\eta_{t h b}$ : Thermal efficiency of the engine, $35 \%$ for diesel engines

427: Thermo-mechanical equivalent, $\mathrm{Kg}$. m/kcal 
$\eta_{m}$ : Mechanical efficiency of the engine, $83 \%$ for diesel engines

\section{- Energy requirements}

Energy requirement was estimated according to fuel consumption for implement by the following equation.

Energy requirements $(\mathrm{kW} . \mathrm{h} / \mathrm{fed})=\frac{\text { Required power }(\mathrm{kW})}{\text { Actual field capacity }(\text { fed } / \mathrm{h})}$
4he operational cost

The cost of mechanized operations is based on the initial cost of machine, interest on capital, cost fuel, oil consumed, cost of maintenance and wage of the operator according to the following formula of (Awady, 1978).

Where:

$$
c=P / h\left(\frac{1}{e}+\frac{i}{2}+t+r\right)+(0.9 h p \times f \times s)+\frac{W}{144}
$$

$c$ : Hourly cost, L.E./h

$P$ : Capital investment, L.E

$h$ : Yearly operating hours.

$e$ : Life expectancy of the machine, year

i: Annual interest rate, $\%$

$t$ : Taxes and over heads ratio, $\%$

r: Annual repairs and maintenance rate, $\%$

0.9: A factor including reasonable estimation of the oil consumption in additions to fuel

$h p$ : Horse power of engine, hp

$f$ : Specific fuel consumption, lit/hp.h

$s$ : Fuel price, L.E./lit

$W$ : Labor wage rate per month, L.E.

144: Reasonable estimation of monthly working hours

The operational cost can be determined by using the following formula

$$
\text { Operational } \cos t(\text { L.E./ fed })=\frac{\text { Machine hourly cost }(\text { L.E./ h })}{\text { Actual field cap acity }(\text { fed } / \mathrm{h})}
$$

\section{RESULTS AND DISCUSSION}

The acquired results will be discussed under the following heads:

\section{Soil bulk density}

Soil bulk density is a very important parameter that reflecting the status of soil compaction and the status of soil porosity. Fig. (3) showed the effect of different agricultural operations on the average reduction of soil bulk density. The reduction of bulk density generally, increased due to tillage with the exception of land leveling. It was noticed that the reduction of soil bulk density were higher under treatment (B) comparing with treatment (A). 


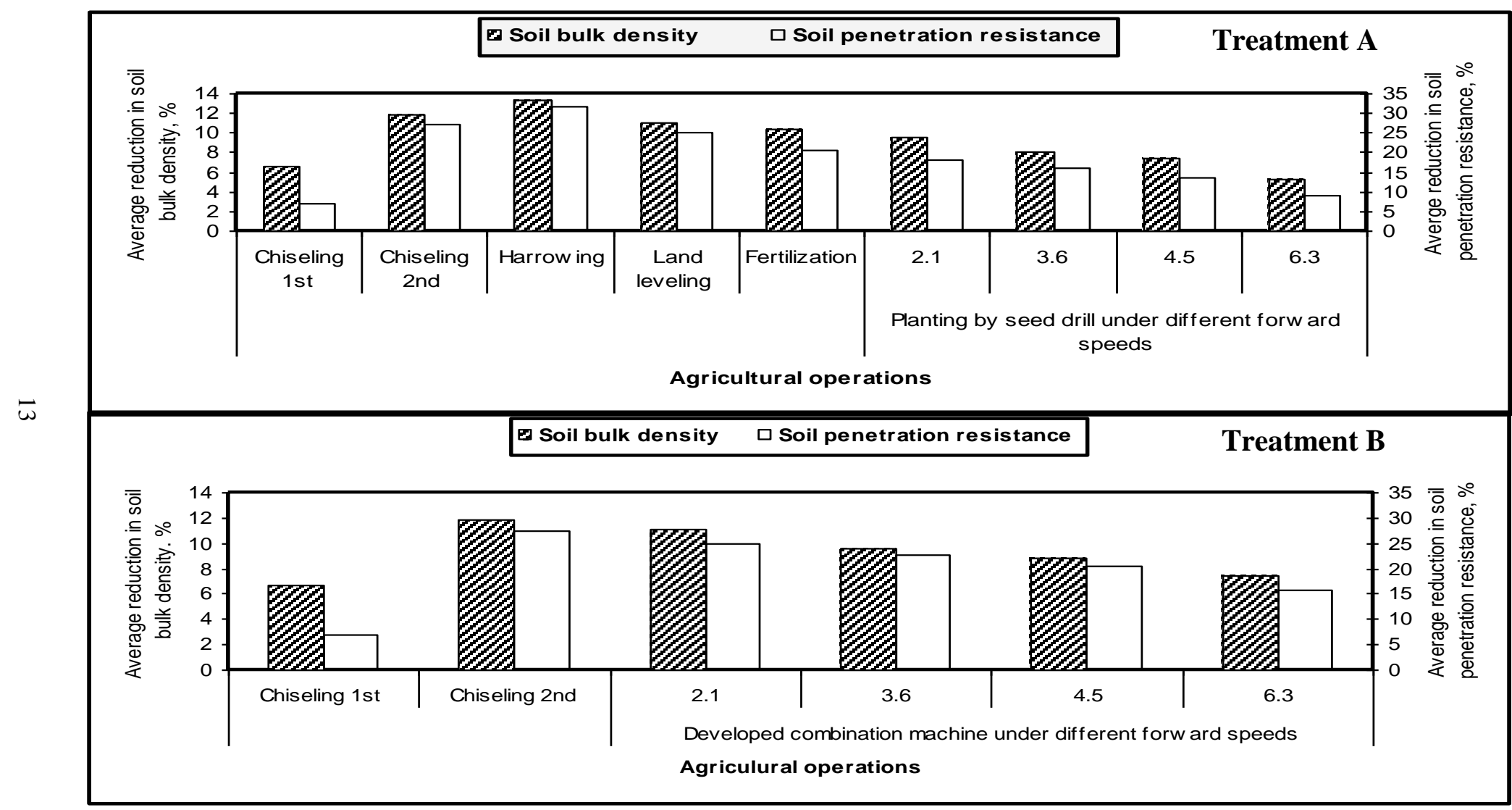

Fig. (3): Effect of different agricultural operations on the reduction of soil bulk density and soil penetration resistance 
This may be due to the reduction in number of machines traffics under the use of the combination machine that carried out many operations at only one pass and so, the danger of soil compaction was reduced. More machines traffics can damage and reduce soil structure. The effectiveness of increasing forward speed represented a hindrance to produce enough air, moisture to help seed grow, root elongate and nutrient spread through soil layers. The maximum reduction in bulk density of $11.11 \%$ was observed under treatment (B) at a forward speed of $2.1 \mathrm{~km} / \mathrm{h}$, while the lowest reduction of $5.19 \%$ was observed under treatment (A) at forward speed of $6.3 \mathrm{~km} / \mathrm{h}$.

\section{Soil penetration resistance}

Fig. (3) showed the effect of different agricultural operations on the average reduction of soil penetration resistance. It was evident that the reduction of penetration resistance was less in treatment (A) than treatment (B), because soil compaction increased by increasing number of machines traffics. The maximum reduction in soil penetration resistance was $25 \%$ at $2.1 \mathrm{~km} / \mathrm{h}$ forward speed under treatment (B), while the minimum reduction was $9.10 \%$ under treatment (A) at forward speed of $6.3 \mathrm{~km} / \mathrm{h}$. The increase in soil penetration resistance was because of less breakdown that would be resulted at higher speeds, which decreased loosening and increased soil aggregates.

\section{Seed scattering}

Seed scattering is very important parameter to determine the performance of planting machines under different forward speeds. Fig. (4) showed the effect of forward speed for both machines (seed drill and developed combination machine) on seed scattering. Generally, seed scattering were increased by increasing the planting forward speed. This may be due to more slip occurred and the increase of planting machine vibration. Increasing forward speed from 2.1 to $6.3 \mathrm{~km} / \mathrm{h}$, increased seed scattering in fennel from 5.90 to $8.59 \%$ for seed dill and from 3.95 to $6.98 \%$ for developed combination machine, respectively. In caraway, scattering increased from 6.10 to $8.96 \%$ and from 4.03 to $7.13 \%$ under the same conditions for the previous mentioned machines. The obtained data indicated that, the developed combination machine gave the least values of seed scattering at different forward speeds comparing with seed drill. 
(Fennel)

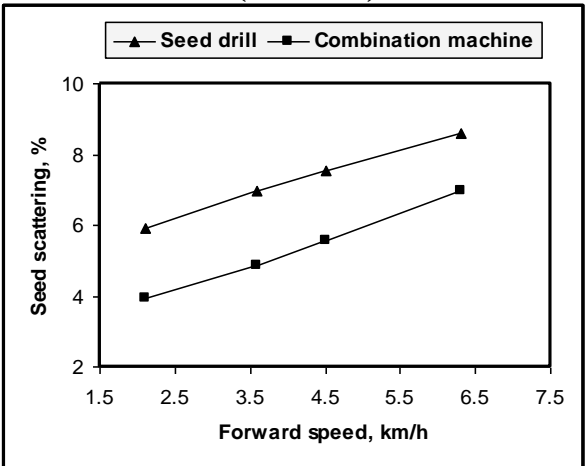

(Caraway)

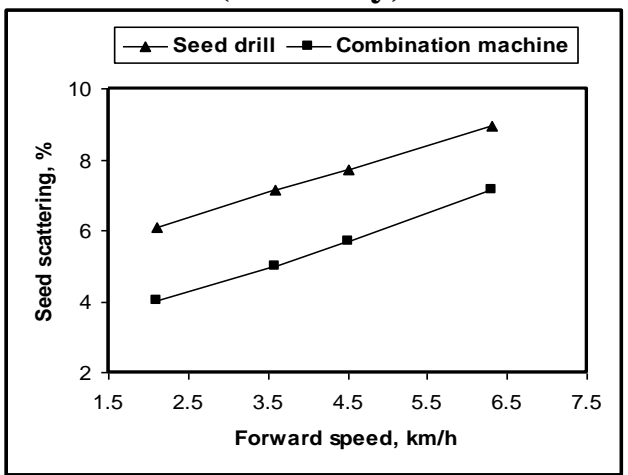

Fig. (4): Effect of forward speed on seed scattering for fennel and caraway under seed drill and developed combination machine

(Fennel)

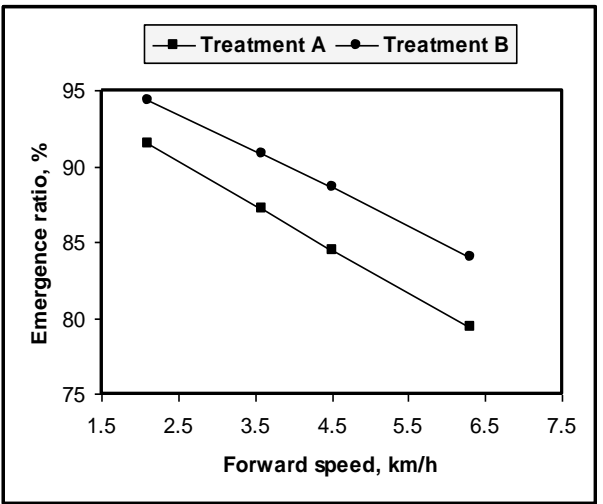

(Caraway)

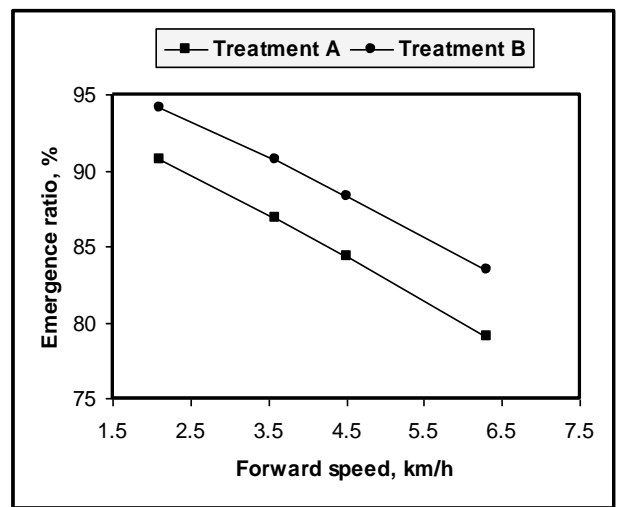

Fig. (5): Effect of forward speed on emergence ratio for fennel and caraway under different treatments

Because the developed machine was heavier than the seed drill, consequently it had less vibration and less lateral seed scattering.

\section{Emergence ratio}

Effect of forward speed on emergence ratio under different treatments was shown in Fig. (5). Results showed that the emergence ratio was affected by seedbed preparation, planting method and planting forward speed. Concerning fennel, increasing forward speed from 2.1 to $6.3 \mathrm{~km} / \mathrm{h}$, decreased emergence ratio from 91.49 to $79.43 \%$ for treatment (A) and from 94.33 to $83.69 \%$ for treatment (B), respectively. Relating to caraway, increasing forward speed from 2.1 to $6.3 \mathrm{~km} / \mathrm{h}$, decreased emergence ratio from 90.73 to $79.02 \%$ for treatment (A) and from 94.15 to $83.41 \%$ for treatment (B), respectively. These results indicated that, 
treatment (B) surpassed treatment (A) in the emergence ratio. This was due to the degree of pressing and firming of the soil around the seed and less soil compaction, which provided by developed machine. And also, increased number of machines traffics delayed emergence ratio under treatment (A), while the developed machine carried out many operations in one pass.

\section{Fruit yield}

Effect of forward speed on fruit yield under different treatments was shown in Fig. (6). Results showed that increasing forward speed from 2.1 to $6.3 \mathrm{~km} / \mathrm{h}$, decreased the fennel yield by $5.34 \%$ under treatment (A) and by $5.01 \%$ under treatment (B), while caraway yield decreased by $4.17 \%$ under treatment (A) and by $4.29 \%$ under treatment (B) at the same mentioned forward speeds. This attributed to the low plant number due to the low emergence at high forward speeds. Increased number of machines traffics delayed seedling emergence and the emergence ratio under treatment (A), while the developed machine carried out many operations in one pass (secondary tillage, fertilizing and planting) and so, the reduction in the danger of soil compaction, resulting in higher yield under treatment (B) comparing with treatment (A).

\section{Field capacity and field efficiency}

Concerning the effect of different agricultural operations on field capacity and field efficiency, field capacity and field efficiency varied from operation to another due to the wide variation in both working width and working speed of each machine as shown in Fig. (7).Results showed that values of field capacity were 1.10, 1.26, 1.02, 1.20 and $1.68 \mathrm{fed} / \mathrm{h}$ for chiseling $1^{\text {st }}$, chiseling $2^{\text {nd }}$, harrowing, land leveling and fertilization, respectively. It was obvious that field capacity increased in chiseling $2^{\text {nd }}$ than chiseling $1^{\text {st }}$, because the loosen soil after the first chiseling enable the plow to work at higher forward speeds so, field capacity was increased at the same working width. While, the field efficiency values were $73.33,72.00,71.33,70.18$ and $84.00 \%$ under the same previous operations, respectively. Relating to the effect of forward speed on field capacity and field efficiency, Fig. (8) showed that increasing forward speed, increased field capacity and the vice versa was noticed with field efficiency from 0.39 to $0.81 \mathrm{fed} / \mathrm{h}$ for the developed 
(Fennel)

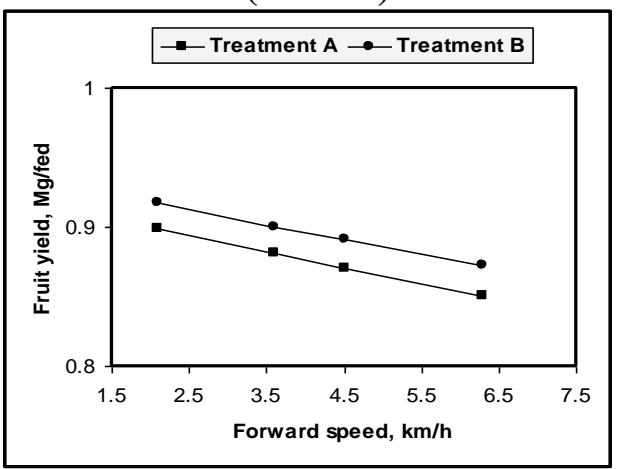

(Caraway)

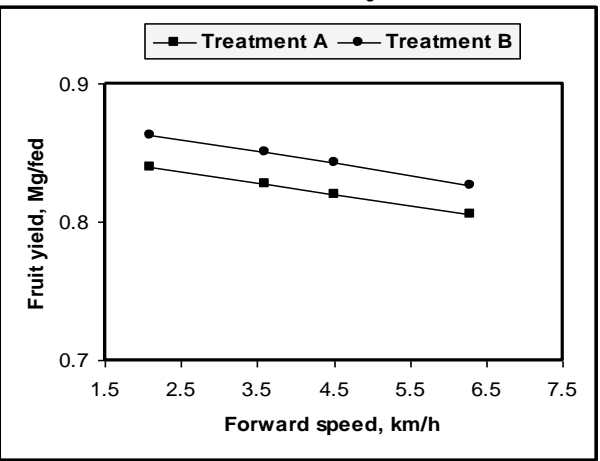

Fig. (6): Effect of different treatments on fruit yield for fennel and caraway under different forward speeds
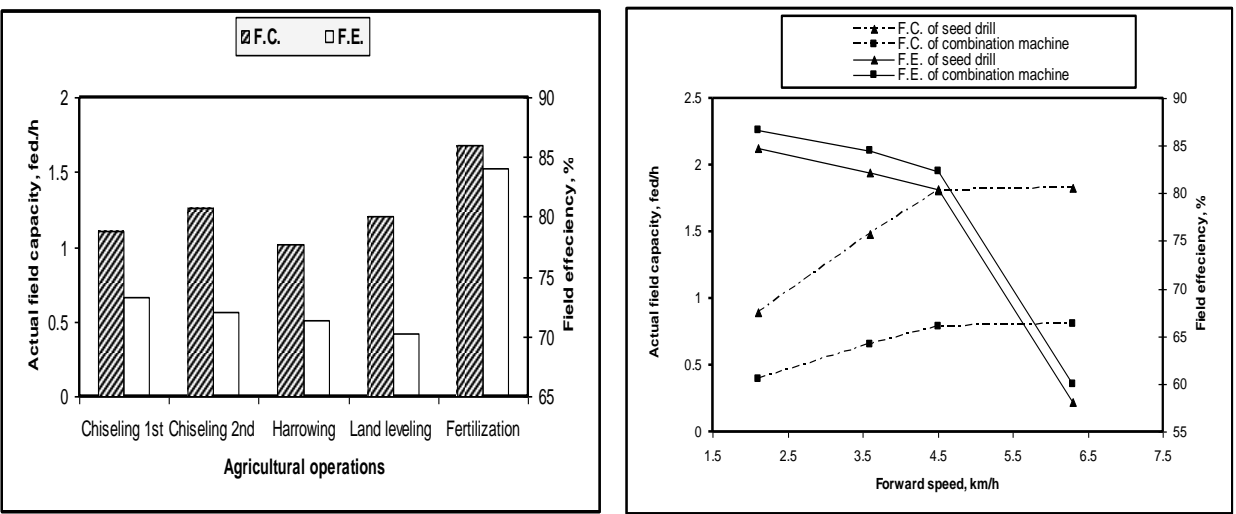

Fig. (7): Effect of different Fig. (8): Effect of forward speed agricultural operations on field on field capacity and field capacity and field efficiency efficiency

combination machine under the Increasing forward speed from 2.1 to $6.3 \mathrm{~km} / \mathrm{h}$, increased field capacity of seed drill from 0.89 to $1.83 \mathrm{fed} / \mathrm{h}$, while the field capacity increased same speed conditions. The values of field capacity for seed drill were higher than the developed combination machine, because of the increase of seed drill working width comparing with the developed machine at the same conditions of forward speeds. Field efficiency values were decreased by increasing the forward speed. Increasing forward speed from 2.1 to $6.3 \mathrm{~km} / \mathrm{h}$, decreased field efficiency values from 84.76 to $58.10 \%$ and from 86.67 to $60.00 \%$ for seed drill and developed combination machine, respectively. The major reason for this reduction in field efficiency by increasing forward speed was due to the less theoretical time consumed in comparison with the other items of time losses. 
(Fennel)

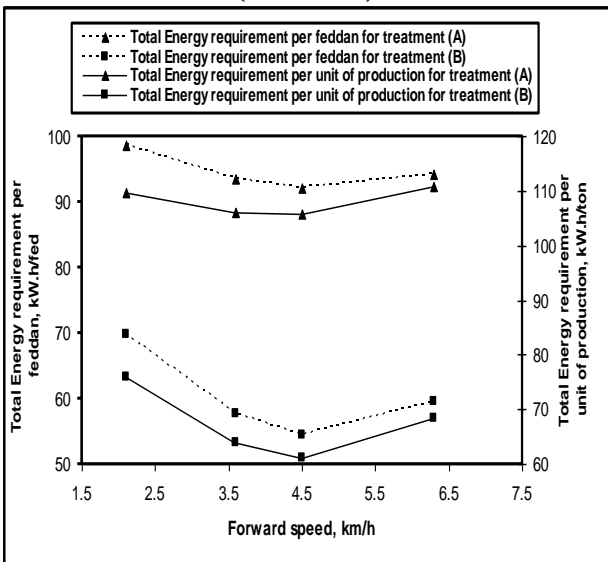

(Caraway)

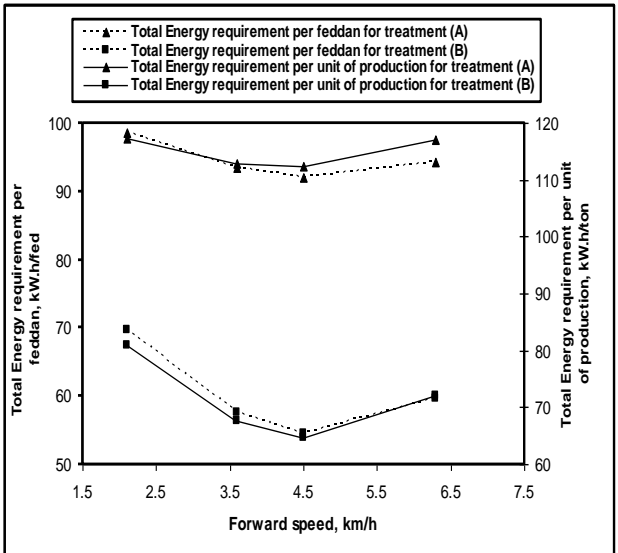

Fig. (9): Effect of different treatments on total energy requirements for fennel and caraway under different forward speeds

(Fennel)

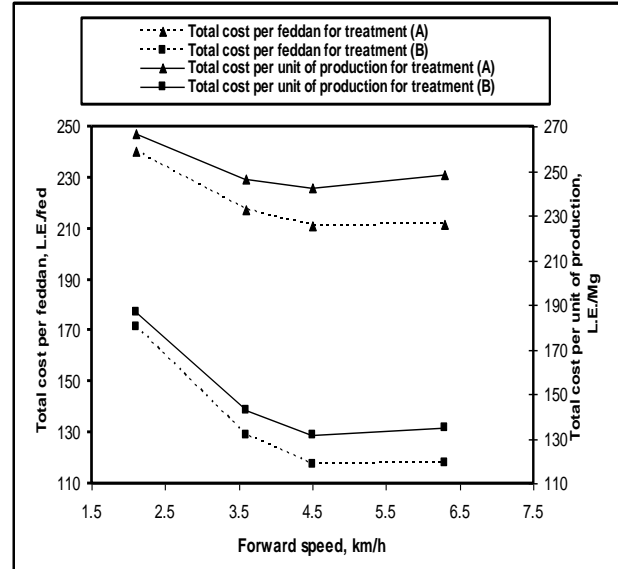

(Caraway)

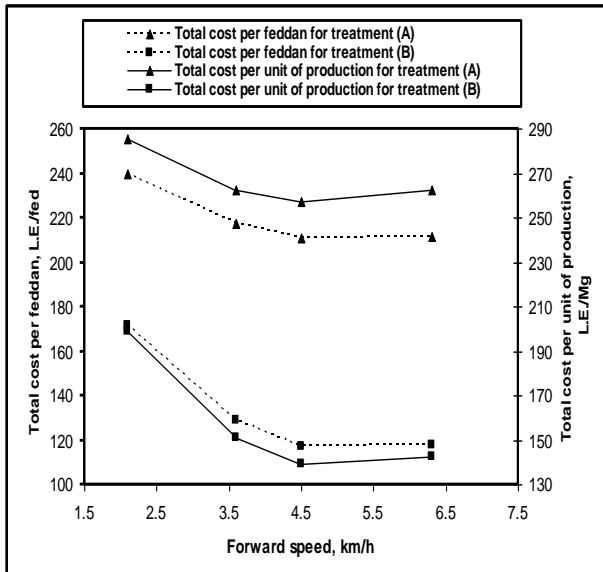

Fig. (10): Effect of different treatments on total cost for fennel and caraway under different forward speeds

\section{Energy requirements}

Fig. (9) showed the effect of different treatments on the energy requirements under different forward speeds. It was clear that the unit of fennel production $(\mathrm{Mg})$, required $105.80 \mathrm{~kW} . \mathrm{h}$ under treatment $(\mathrm{A})$ and $61.14 \mathrm{~kW}$.h under treatment (B) at forward speed of $4.5 \mathrm{~km} / \mathrm{h}$ and the unit of production for caraway $(\mathrm{Mg})$, required $112.26 \mathrm{~kW}$.h under treatment (A) and $64.63 \mathrm{~kW} . \mathrm{h}$ under treatment (B). Treatment (B) saved energy per unit of production by $42.21 \%$ for fennel and $42.43 \%$ for caraway at forward speed of $4.5 \mathrm{~km} / \mathrm{h}$. The decrease in the energy requirements 
under treatment (B) comparing with treatment (A) could be explained by the fact that the combination machine carried out three operations in only one pass, consuming less fuel, requiring less power, resulting in low energy requirements.

\section{Operational cost}

Fig. (10) showed the effect of different treatments on total operational cost under different forward speeds. Results explained that, the total operational cost for treatment (B) was less than treatment (A). At forward speed of $4.5 \mathrm{~km} / \mathrm{h}$, the cost reduction per unit of production under treatment (B) was $45.68 \%$ in fennel and $45.89 \%$ in caraway. The main reason for the cost reduction under treatment (B) comparing with treatment (A) was attributed to the fact that the developed combination machine was operated as a multi-purposes machine for secondary tillage, fertilizing and planting in one pass.

\section{CONCLUSION}

\section{Based on the obtained results in this study, the following} recommendations can be drawn:

1. The lowest reduction of soil bulk density was $5.19 \%$ for treatment A and $7.41 \%$ for treatment B at forward speed of $\quad 6.3 \mathrm{~km} / \mathrm{h}$.

2. The developed combination machine gave the least values of seed scattering at different forward speeds comparing with seed drill.

3. By increasing forward speed from 2.1 to $6.3 \mathrm{~km} / \mathrm{h}$, decreased the fennel yield by $5.34 \%$ under treatment (A) and by $5.01 \%$ under treatment (B), while caraway yield decreased by $4.17 \%$ under treatment (A) and by $4.29 \%$ under treatment (B) at the same mentioned forward speed.

4. Treatment (B) saved energy per unit of production by $42.21 \%$ for fennel and $42.43 \%$ for caraway at forward speed of $4.5 \mathrm{~km} / \mathrm{h}$.

5. The cost reduction per unit of production under treatment (B) was $45.68 \%$ in fennel and $45.89 \%$ in caraway at forward speed of 4.5 $\mathrm{km} / \mathrm{h}$. 


\section{REFERENCES}

Abdou, F. M. (1995). Design of combination unit for seed preparation and seed drill suitable for wheat, rice and barely crops. Misr J.

Agric. Eng., 12 (3): $624-649$.

Awady, M. N. (1978). Engineering of tractors and agricultural machinery. Textbook, Col. Agric. Ain Shams Univ.: 174 p. (in Arabic).

Bertocco, M. (2007). Combination seed drills. Informatore-Agrario. 63(29): $51-57$.

Black, C. A; D. D. Evan; J. L. White; L. E. Ensimenger and L. E. Clark (1965). Methods of soil analysis. Pub. Wisconsin, U.S.A.

El-Eshmawy, Kh. H. and A. I. Ali (2010). An Economic study of the costs of production of some medicinal and aromatic plants in Fayoum Governoate. American-Eurasian J. Agric. \& Environ Sci., 7(6): $713-718$.

El-Nakib, A. A. and H. H. Fouad (1990). Effect of minimum tillage with condition implement on soil physical properties. Misr J. Agric. Eng., 7 (2): $121-131$.

Hunt, D. (1983). Farm power and machinery management. 8th Ed. Iowa state Univ., Press Ames, USA. Ames, Iowa, USA: 364-368.

Imbabi, A. T. (2001). Field evaluation of combination unit for seedbed preparation and planting wheat under Egyptian conditions. Misr J. Agric. Eng., 18 (2): 261 - 278.

Kepner, R. A.; R. Bainer and E. Barger (1978). Principles of farm machinery. Third Edition, AVI. publishing company, INC. Westport, Connecticut, U.S.A. 
Morad, M. M; M. N. Sief El-Yazl and M. K. Afify (2001). Development of a combination unit for secondary tillage and seeding wheat crop. Misr J. Agric. Eng., 18 (4): $202-218$.

Snedecor, G. W. and W. G. Cochran (1967). Statistical Methods 6th. Ed., Ames: The Iowa State University U.S.A., Press, 593p.

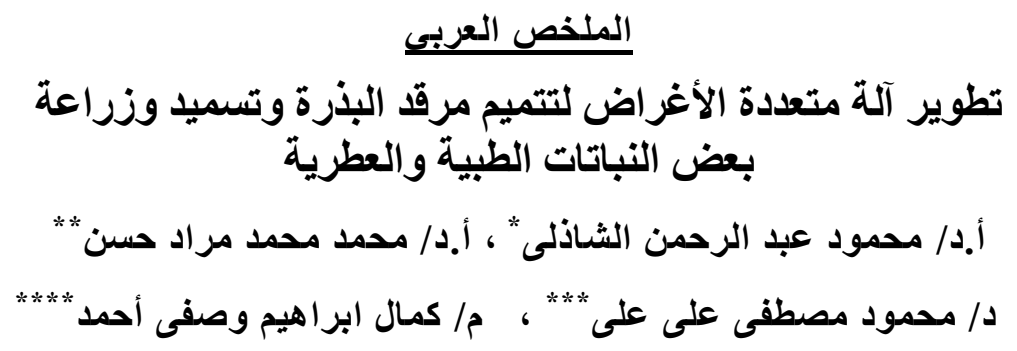

تهدف هذه الدراسة الى التوصية بأفضل النظم التي يمكن الحصول عليها لزر اعـة النباتـات الطبية

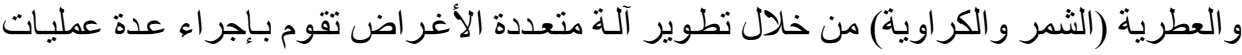

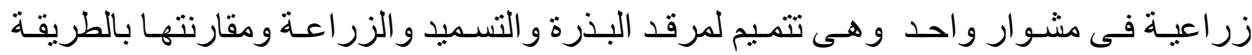

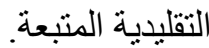

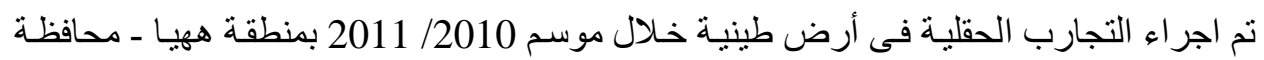

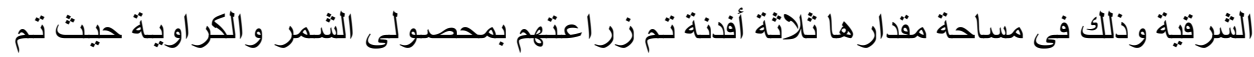

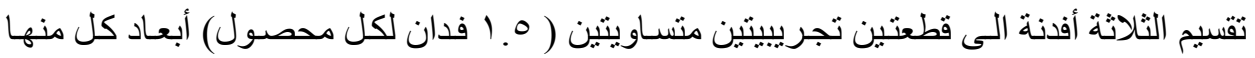
. 7 × $(7.0)$

وقد أجريت التجربة باستخدام المعاملات الآتية:

ـ معاملة (A): حرث وجهين بالدحر اث الحفار + تمشيط بالمشط القرصى + تسوية بالقصابية + تسميد + زر اعة باستخدام السطارة.

معاملة (B): حرث وجهين بـالمحر اث الحفار + الآلة المجمعة لتتميم مرقد البذرة و التسميد

$$
\text { و الزراعة. }
$$

- نو عان مختلفان من النباتات الطبية و العطرية ( الثمر و الكر اوية).

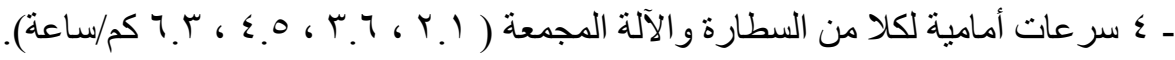
* أستاذ ورئيس قسم الهندسة الزراعية - قسم الهنسة الزراعية- كلية الزراعة - جامعة الزقازيق.

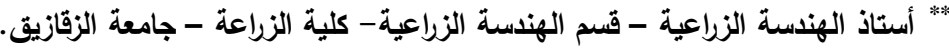

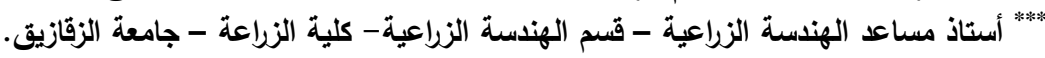
"****** مدرس مساعد - قسم الهندسة الزراعية- كلية الزراعة - جامعة الزقازيق. 


\section{وقد تم دراسة أثر هذه المعاملات على كل من:}

الخو اص الطبيعية للتربة (الكثافـة الظاهريـة للتربة ومقاومـة الاختر اق للتربـة) - التشتت ونسبة

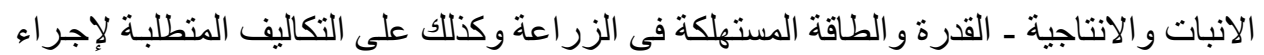
العمليات الزر اعية المختلفة من بداية الاعداد حتى الزر الاعة و التسميد. ومن أهم النتائج المتحصل عليها يمكن التوصية بالآتى:

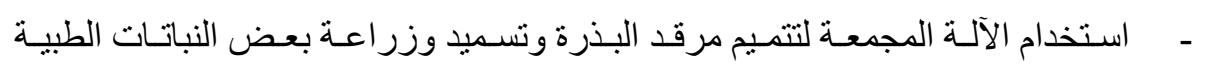

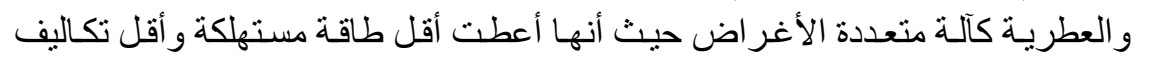

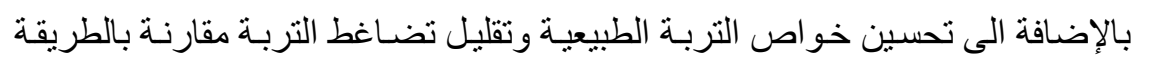
التقليدية.

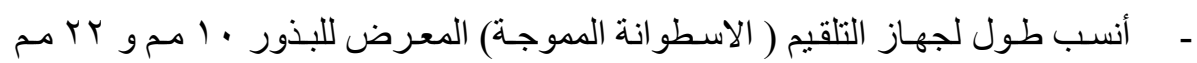

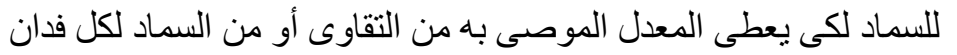

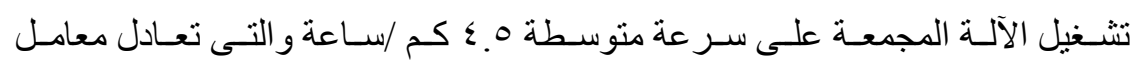

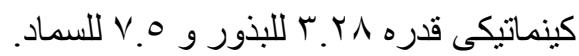

